\title{
Detection of bovine tuberculosis in cattle and buffaloes in three districts of Punjab by immunological and molecular techniques
}

\author{
H. Kaur ${ }^{1}$, G. Filia ${ }^{2 *}$ and S.T. Singh ${ }^{3}$ \\ ${ }^{1}$ Department of Veterinary Microbiology, College of Veterinary Science, Guru Angad Dev Veterinary \\ and Animal Sciences University, Ludhiana - 141 004, Punjab, India; ${ }^{2}$ Animal Disease Research \\ Centre, College of Veterinary Science, Guru Angad Dev Veterinary and Animal Sciences University, \\ Ludhiana - 141 004, Punjab, India; ${ }^{3}$ Directorate of Livestock farm, College of Veterinary Science, \\ Guru Angad Dev Veterinary and Animal Sciences University, Ludhiana- 141 004, Punjab, India
}

\begin{abstract}
This study aimed to diagnose bovine tuberculosis in cattle and buffaloes by Single Intradermal Comparative Tuberculin Test (SICTT), Gamma Interferon ( $\gamma$-IFN) assay and molecular techniques. A total of 230 blood samples were collected from organised and unorganised dairy farms at Ludhiana, Jalandhar and Gurdaspur districts and were subjected to SICTT, $\gamma$-IFN assay and antibody response. Further, molecular diagnosis of Mycobacterium tuberculosis complex (MTC) was done by using conventional IS6110 PCR on blood samples of animals that were reactors in SICTT. Seventeen animals were positive for bTB by SICTT and 21 by $\gamma$-IFN assay. Seventeen animals that were tested positive by SICTT, revealed positive results in $\gamma$-IFN assay. Four negative reactors for bTB with SICTT showed positive with $\gamma$-IFN assay. Further, thirteen animals were positive for antibody response. By PCR, twenty-three animals were positive for MTC. Six animals showing inconclusive results by SICTT were positive by PCR while four $\gamma$-IFN assay negative animals were also tested positive by PCR.
\end{abstract}

Key words: Bovine tuberculosis, IS6110PCR, MTC, SICTT, $\gamma$-IFN

\section{INTRODUCTION}

Bovine tuberculosis is a disease of infectious nature that occurs in livestock and can spread to human by aerosol inhalation or ingestion of unpasteurised milk. This disease has no geographic limits, and infection occurs in farm animals of economic significance along with wildlife. In India, illiteracy is another obstacle in the control of animal tuberculosis, mainly rural communities. Tuberculin skin testing is considered a conventional method for screening bovine tuberculosis. Due to the slowgrowing nature of this organism, its isolation and identification is a challenge. The sensitivity of the traditional microbiological approach (isolation and identification of the Mycobacterium organisms from both live and dead animals) is higher but takes a long time (six-eight weeks). Intradermal tests are comparatively inexpensive and have an uncomplicated procedure, but these are challenging to execute on a large-scale epidemiological surveys. Besides, intradermal tests demand two visits to a farm, and may give a false-negative results in an advanced disease stage with a high bacterial load (Waters et al., 2011). Interferon-Gamma Assays being relatively expensive and requiring qualified staff, are more specific than intradermal tests (Wadhwa et al., 2012). In cattle and buffaloes, parallel skin and Interferon Gamma Assay testing have proved to be very beneficial (Ahir et al., 2006). When practised in a series involving re-testing of skin-test positive animals with a gamma-interferon test, both tests enhance the specificity of testing (Ryan et al., 2000) as if these tests done together will detect the animals which are either in early or late stage of the disease. Antibody-based assays for detecting bTB are being engaged due to their simplicity, flexibility and economic advantages (Wadhwa et al., 2012) as in the present. Cattle 
produce high levels of circulating antibodies against $M$. bovis, late in the course of infection, in more advanced stages of infection or when they are stimulated with high infective doses (Neill et al ., 2001; Welsh et al., 2005). Hence, when antibodies titres are low, serology is less effective in identifying the stages of infection. The antibody-based assays (ELISA) are especially attractive because the animals are handled only once, quick processing of the sample, a large number of animals, can be tested at a time (Harrington et al., 2008).

For the rapid and specific diagnosis of TB, various alternative approaches have been pursued, but molecular methods, particularly PCR assays, are the most promising methods providing accurate recognition of the organism. The most commonly used PCR is based on primers that amplify segments of the IS6110 element, primarily targeting the $245 \mathrm{bp}$ fragments (Figueiredo et al., 2009).

It was envisioned that a well-planned study to analyse all the diagnostic methods, including molecular diagnostic tools, would be helpful in the early and accurate diagnosis of bovine tuberculosis. Hence, the present study was intended to detect bovine tuberculosis using Single Intradermal Cervical Comparative Tuberculin Test (SICCT), Gamma Interferon Release Assay, antibody response by ELISA followed by detection of MTC with PCR.

\section{MATERIALS AND METHODS}

Ethical approval: This study was approved by the Institutional Animal Ethics Committee of Guru Angad Dev Veterinary and Animal Sciences University (GADVASU) [IAEC vide order no: GADVASU/2019/IAEC/53/05]

\section{Screening of animals by Single Intradermal Cervical Comparative Tuberculin Test (SICCT): A total of 230 milch animals (74 cattle and 156 buffaloes) from an organised dairy farm (40 cattle and 140 buffaloes) in Ludhiana and unorganised dairy farms located at Gurdaspur (28 cattle only) and Jalandhar (6 cattle and 16 buffaloes). The study in these three farms was carried out with in a period of six}

months. These three farms selected on the basis of request put forward by the veterinarians on behalf of the owners to get their farms screened for tuberculosis. The animals were divided into four age groups ie 1 to 3 years (4 cattle and 9 buffaloes), 3 to 6 years (16 cattle and 27 buffaloes), 6 to 9 years ( 34 cattle and 80 buffaloes) and 9 to 12 years (20 cattle and 40 buffaloes) to carry out the present study. Symptomatically the herds were free from tuberculosis as no testing had been carried out in the organised or unorganised dairy farms under study. The owners did not report any cough or respiratory problem at their farms. Further there was no history of introduction of new animals inside the two unorganised farms where as four animals were added in the organised farm. The test was performed using bovine tuberculin PPD from the culture of M. bovis (strain AN5, $3000 \mathrm{IU}$ ) and avian tuberculin PPD from the culture of $M$. avium subspecies avium (strain D4ER, 2500 IU) obtained from Prionics (Switzerland) using the standard procedure. Briefly, two 2 x 2 square inch areas were shaved on the left side of the neck, approximately $12-15 \mathrm{~cm}$ apart. The zero hour skin thickness at both the injection site was measured with the help of a vernier calliper. Bovine and avian tuberculin/PPD $(0.1 \mathrm{~mL}$ each $)$ was injected intradermally. Bovine PPD was injected in the upper shaved area, while the avian PPD was injected in the lower shaved area of the neck. The correct injection was confirmed by palpation of a small pea-like swelling at the site. Inflammatory responses were recorded 72 hours following injection. Observations were recorded if there is swelling at the site of injection. Animals were considered positive if the increase in skin thickness at the bovine site of injection was greater than $4 \mathrm{~mm}$ than the reaction shown at the site of the avian injection. The reaction is considered to be negative if the increase in skin thickness at the bovine site of injection is less than or equal to the increase in the skin reaction at the avian site of injection. If the increase in skin thickness at the bovine site of injection is greater than the avian reaction with a difference between $1 \mathrm{~mm}$ to $4 \mathrm{~mm}$, then 
the results are considered as inconclusive.

\section{Screening of animals by Interferon Gamma}

Release Assay: This test was performed using Mycobacterium bovis Gamma Interferon bovigam ${ }^{\circledR}$ Test kit. BOVIGAM ${ }^{\circledR}$ is a rapid in-vitro blood-based assay of cell-mediated immune response to $M$. bovis PPD tuberculin for the diagnosis of bovine tuberculosis infection. The test was performed in two stages, i.e. in the first stage, tuberculin PPD antigens were presented to lymphocytes in blood collected from animals. In the second stage, the production of gamma-interferon from cells was detected using monoclonal antibodybased enzyme immunoassay (EIA). Lymphocytes from animals not infected with M. bovis did not produce gamma-interferon. Therefore detection of gamma-interferon correlates to $M$. bovis infection. The test was performed as per the standard protocol described by manufacturer.

Screening of animals for detection of humoral response by ELISA: The antibody response was studied using BIO NOTE BTB Ab ELISA 2.0 kit. It is a direct Enzyme-Linked Immunosorbent Assay for the qualitative detection of Mycobacterium bovis antibody in serum. The BIO NOTE BTB Ab ELISA $2.0 \mathrm{kit}$ contains a microplate, which is pre-coated with purified bTB antigen on the wells. The procedure recommended by the manufacturer was followed for the detection of antibodies against Mycobacterium bovis.

Screening of animals by PCR: DNA extraction was carried out using DNeasy Blood and Tissue kit (Qiagen). Blood samples from a total of 50 animals which were positive and inconclusive reactors by SICCT were included for this study. Whole blood sample $(1 \mathrm{~mL})$ collected from the reactor animals was centrifuged at $14,000 \mathrm{rpm}$ for 10 minutes. The pellet was suspended in lysis buffer, and further DNA extraction was done as per the manufacturer's protocol and stored at $-20^{\circ} \mathrm{C}$ till further use. This was followed by the amplification of the DNA using primers specific for IS6110 sequence targeting 245 bps fragments for MTC members.

Polymerase Chain Reaction was performed as per the protocol mentioned in Figueiredo et al. (2009) using INS1/INS2 with some modifications. Briefly, a reaction volume of 25 $\mu \mathrm{L}$ was made containing $12.5 \mu \mathrm{L}$ of Taq PCR Master Mix, $1 \mu \mathrm{L}$ of forwarding primer (10 $\mathrm{pmol} / \mu \mathrm{L}), 1 \mu \mathrm{L}$ of reverse primer $(10 \mathrm{pmol} / \mu \mathrm{L})$, $0.5 \mu \mathrm{L}$ of nuclease-free water and $10 \mu \mathrm{L}$ of DNA template. Thermal cycling was performed in Temperature Gradient Thermocycler (Biometra, Germany), and cycling conditions were as follows, initial denaturation at $94^{\circ} \mathrm{C}$ for $5 \mathrm{~min}$, followed by 29 cycles of denaturation at $94^{\circ} \mathrm{C}$ for $1 \mathrm{~min}$, annealing at $63^{\circ} \mathrm{C}$ for $1 \mathrm{~min}$, extension at $72^{\circ} \mathrm{C}$ for $1 \mathrm{~min}$ and final extension at $72^{\circ} \mathrm{C}$ for $7 \mathrm{~min}$. Polymerase chain reaction products were analysed by gel electrophoresis using $1.5 \%$ agarose gel and visualised by a gel documentation system (Bio-Rad) (Fig. 1).

\section{RESULTS}

SICCT: A total of 230 milch animals (74 cattles and 156 buffaloes) were tested, out of which 17 $(7.3 \%)$ were positive reactors, $34(14.7 \%)$ animals were inconclusive reactors, and 179 $(77.8 \%)$ were negative. Out of the total 74 cattle, only one $(1.3 \%)$ was a positive reactor, 16 $(21.6 \%)$ were inconclusive, and $57(77 \%)$ were negative. Out of a total of 156 buffaloes, 16 $(10.2 \%)$ were positive, $17(10.8 \%)$ were inconclusive, and $123(78.8 \%)$ were negative. In the present study prevalence of bTB shown by cattle and buffaloes was $1 / 74(1.3 \%)$ and $16 / 156(10.2 \%)$, respectively. Out of a total of 180 animals belonging to an organised farm, 15 animals $(8.3 \%)$ were positive reactors. All of these animals were buffaloes belonging to an organised dairy farm. On the other hand, out of 50 animals belonging to two unorganised farms, 2 animals $(4 \%)$ were positive reactors ( 1 cattle and 1 buffalo) (Table 1). Age wise none of the animals were positive in 1 to 3 years and 3 to 6 years age groups. In age group of 6 to 9 years 9 animals were positive by tuberculin test while in 9 to 12 years age group 8 animals were positive. 


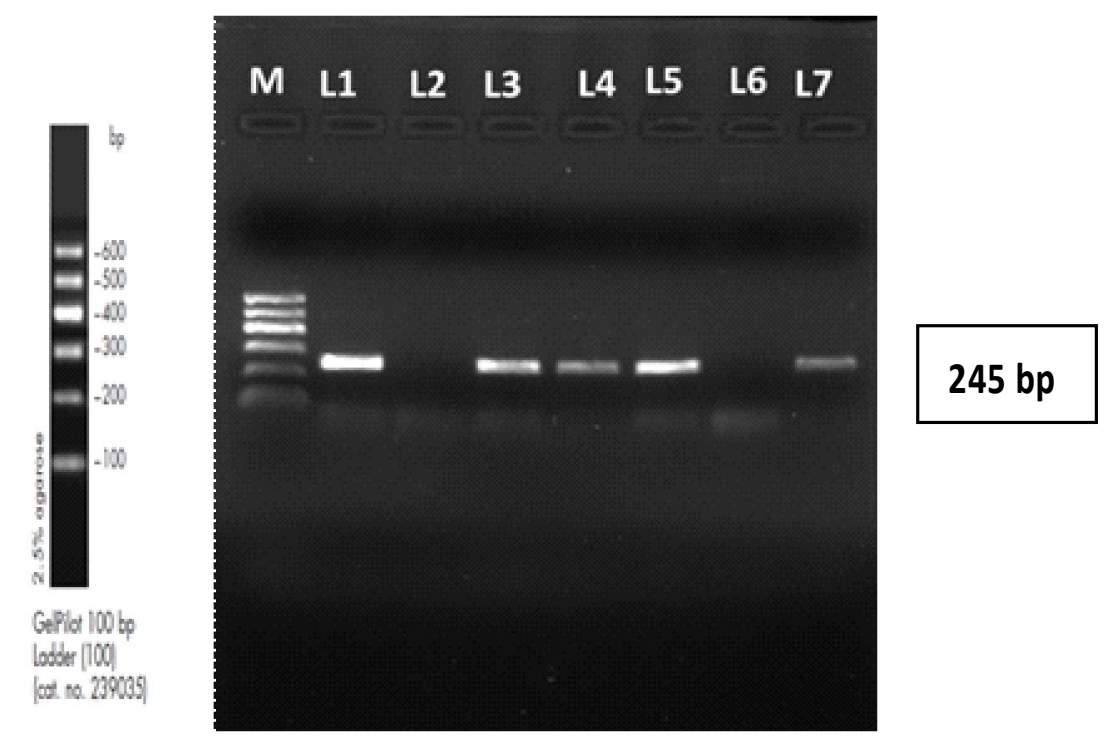

M: DNA 100bp ladder, L1: Positive control, L2: Negative control, L3-L7: Samples

Fig. 1. Agarose gel electrophoresis of the amplified IS6110 gene of MTC using INS1/INS2 primers

Interferon Gamma Release Assay: In the present study, a total of 230 animals tested by c-IFN assay, 21 animals $(9.1 \%)$ were positive ( 3 cattle and 18 buffaloes) (Table 2). One cattle and 16 buffaloes that were tested positive by SICTT, displayed positive results in $\gamma$-IFN assay. Out of 17 cattle that were inconclusive reactors by SICTT, two tested positive by $\gamma$-IFN assay. On the other hand, out of 17 inconclusive buffaloes, two tested positive by $\gamma$-IFN assay (Table 3).
ELISA: A total of 230 animals were tested by using BIO NOTE BTB Antibody ELISA 2.0 kit, out of which 13 animals (5.6\%) were positive. The prevalence of bTB antibody in cattle and buffaloes using ELISA was 0/74 (0\%) and $13 / 156(8.3 \%)$, respectively (Table 4$)$.

PCR: The PCR assay of the DNA amplified from the blood samples was positive for MTBC in 23 (46\%) out of a total of 50 reactor (both positive and inconclusive) animals. Three cattle (17.6\%) and 20 buffaloes $(60 \%)$ displayed positive tests (Table 5).

Table. 1. Comparative Intradermal Tuberculin test for screening of animals for bovine tuberculosis

\begin{tabular}{|c|c|c|c|c|c|c|c|c|}
\hline \multirow[t]{2}{*}{ Farm } & \multicolumn{4}{|c|}{ Cattle } & \multicolumn{4}{|c|}{ Buffalo } \\
\hline & Positive & Inconclusive & Negativ & Total & Positive & Inconclusive & Negative & Total \\
\hline $\begin{array}{l}\text { Organized } \\
\text { (Farm-1) } \\
\mathrm{N}=180\end{array}$ & 0 & $\begin{array}{c}6 \\
(15 \%)\end{array}$ & 34 & 40 & $\begin{array}{c}15 \\
(10 \%)\end{array}$ & $\begin{array}{c}12 \\
(8.5 \%)\end{array}$ & 113 & 140 \\
\hline $\begin{array}{l}\text { Unorganized } \\
\text { (Farm-2) } \\
\mathrm{N}=22\end{array}$ & 0 & $\begin{array}{c}4 \\
(66 \%)\end{array}$ & 2 & 6 & $\begin{array}{c}1 \\
(16.2 \%)\end{array}$ & $\begin{array}{c}5 \\
(31.2 \%)\end{array}$ & 10 & 16 \\
\hline $\begin{array}{l}\text { Unorganized } \\
(\text { Farm-3) } \\
\mathrm{N}=28\end{array}$ & $\begin{array}{c}1 \\
(3.5 \%)\end{array}$ & $\begin{array}{c}6 \\
(21.4 \%)\end{array}$ & 21 & 28 & - & - & - & - \\
\hline Total & $\begin{array}{c}1 \\
(1.3 \%)\end{array}$ & $\begin{array}{c}16 \\
(21.6 \%)\end{array}$ & 57 & 74 & $\begin{array}{c}16 \\
(10.2 \%)\end{array}$ & $\begin{array}{c}17 \\
(10.8 \%)\end{array}$ & 123 & 156 \\
\hline
\end{tabular}


Table. 2. Gamma Interferon Assay for screening of animals for bovine tuberculosis

\begin{tabular}{|c|c|c|c|c|c|c|}
\hline \multirow[t]{2}{*}{ Farm } & \multicolumn{3}{|c|}{ Cattle } & \multicolumn{3}{|c|}{ Buffalo } \\
\hline & Positive & Negative & Total & Positive & Negative & Total \\
\hline $\begin{array}{l}\text { Organized } \\
(\text { Farm-1) } \\
N=180\end{array}$ & $\begin{array}{c}2 \\
(5 \%)\end{array}$ & $\begin{array}{c}38 \\
(95 \%)\end{array}$ & 40 & $\begin{array}{c}16 \\
(11.4 \%)\end{array}$ & $\begin{array}{c}124 \\
(88.5 \%)\end{array}$ & 140 \\
\hline $\begin{array}{l}\text { Unorganized } \\
(\text { Farm-2) } \\
\mathrm{N}=22\end{array}$ & 0 & $\begin{array}{c}6 \\
(100 \%)\end{array}$ & 6 & $\begin{array}{c}2 \\
(12.5 \%)\end{array}$ & $\begin{array}{c}14 \\
(87.5 \%)\end{array}$ & 16 \\
\hline $\begin{array}{l}\text { Unorganized } \\
\text { (Farm-3) } \\
\mathrm{N}=28\end{array}$ & $\begin{array}{c}1 \\
(3.5 \%)\end{array}$ & $\begin{array}{c}27 \\
(96.4 \%)\end{array}$ & 28 & - & - & - \\
\hline Total & $\begin{array}{c}3 \\
(4 \%)\end{array}$ & $\begin{array}{c}71 \\
(96 \%)\end{array}$ & 74 & $\begin{array}{c}18 \\
(11.5 \%)\end{array}$ & $\begin{array}{c}138 \\
(88.4 \%)\end{array}$ & 156 \\
\hline
\end{tabular}

Table. 3. Comparison of results of Comprarative Intradermal Tuberculin test and Gamma Interferon Assay

\begin{tabular}{l|ccc|ccc}
\hline CITT & \multicolumn{3}{|c|}{ Cattle } & \multicolumn{3}{c}{ Buffalo } \\
\cline { 2 - 7 } & $\begin{array}{c}\text { IFN }-\gamma \\
\text { positive }\end{array}$ & $\begin{array}{c}\text { IFN }-\gamma \\
\text { Negative }\end{array}$ & Total & $\begin{array}{c}\text { IFN }-\gamma \\
\text { positive }\end{array}$ & $\begin{array}{c}\text { IFN }-\gamma \\
\text { Negative }\end{array}$ & Total \\
\hline CITT positive & 1 & 0 & 1 & 16 & 0 & 16 \\
CITT negative & 0 & 56 & 56 & 0 & 123 & 123 \\
Inconclusive & 2 & 15 & 17 & 2 & 15 & 17 \\
\hline Total & $\mathbf{3}$ & $\mathbf{7 1}$ & $\mathbf{7 4}$ & $\mathbf{1 8}$ & $\mathbf{1 3 8}$ & $\mathbf{1 5 6}$ \\
\hline
\end{tabular}

Table. 4. Results of detection of antibodies against bovine tuberculosis

\begin{tabular}{|c|c|c|c|c|c|c|}
\hline \multirow[t]{2}{*}{ Farm } & \multicolumn{2}{|c|}{ Cattle } & \multirow[b]{2}{*}{ Total } & \multicolumn{3}{|c|}{ Buffalo } \\
\hline & Positive & Negative & & Positive & Negative & Total \\
\hline $\begin{array}{l}\text { Organized } \\
(\text { Farm-1) } \\
\mathrm{N}=180\end{array}$ & 0 & $\begin{array}{c}40 \\
(100 \%)\end{array}$ & $\begin{array}{c}40 \\
(9.2 \%)\end{array}$ & 13 & $\begin{array}{c}127 \\
(90.2 \%)\end{array}$ & 140 \\
\hline $\begin{array}{l}\text { Unorganized } \\
\text { (Farm-2) } \\
\mathrm{N}=22\end{array}$ & 0 & $\begin{array}{c}6 \\
(100 \%)\end{array}$ & $\begin{array}{c}6 \\
(100 \%)\end{array}$ & 0 & 16 & 16 \\
\hline $\begin{array}{l}\text { Unorganized } \\
\text { (Farm-3) } \\
\mathrm{N}=28\end{array}$ & 0 & $\begin{array}{c}28 \\
(100 \%)\end{array}$ & 28 & - & - & - \\
\hline Total & $0(0 \%)$ & $\begin{array}{c}74 \\
(100 \%)\end{array}$ & $\begin{array}{c}74 \\
(8.3 \%)\end{array}$ & 13 & $\begin{array}{c}143 \\
(91.6 \%)\end{array}$ & 156 \\
\hline
\end{tabular}


Table. 5. Animals positive by Polymerase Chain Reaction for Mycobacterium tuberculosis complex

\begin{tabular}{l|ccc|ccr}
\hline \multirow{2}{*}{ Farm } & \multicolumn{3}{|c|}{ Cattle } & \multicolumn{3}{c}{ Buffalo } \\
\cline { 2 - 7 } & Positive & Negative & Total & Positive & Negative & Total \\
\hline $\begin{array}{l}\text { Organized } \\
\text { (Farm-1) }\end{array}$ & 2 & 4 & 6 & 18 & 9 & 27 \\
$\mathrm{~N}=33$ & $(33.3 \%)$ & $(66.6 \%)$ & & $(66.6 \%)$ & $(33.3 \%)$ & \\
$\begin{array}{l}\text { Unorganized } \\
(\text { Farm-2) }\end{array}$ & - & 4 & 4 & 2 & 4 & 6 \\
$\mathrm{~N}=10$ & & $(100 \%)$ & & $(33.3 \%)$ & $(66.6 \%)$ & \\
$\begin{array}{l}\text { Unorganized } \\
(\text { Farm-3) }\end{array}$ & 1 & 6 & & & & \\
$\mathrm{~N}=7$ & $(14.2 \%)$ & $(85.7 \%)$ & & & & \\
\hline TotalN $=\mathbf{5 0}$ & $\mathbf{3}$ & $\mathbf{1 4}$ & & & & \\
& $(\mathbf{1 7 . 6 \% )}$ & $(\mathbf{8 2 . 3 \% )}$ & $\mathbf{1 7}$ & $\mathbf{2 0}$ & $\mathbf{1 3}$ & $\mathbf{3 3}$ \\
\hline
\end{tabular}

\section{DISCUSSION}

Tuberculosis is a chronic wasting disease caused by the Mycobacterium tuberculosis complex (MTC). M. bovis belonging to MTC, is one of the major causative agents of tuberculosis in dairy animals and many other domestic as well as wild animals. Immune response against Mycobacterium is predominantly cellular. The delayed type of immune response as elicited by a single intradermal tuberculin test is not very specific and has several limitations in detecting bovine tuberculosis in cattle and buffaloes. The Gamma Interferon Release Assay (IGRA) is a rapid blood-based assay of cell-mediated immune response for the diagnosis of bovine tuberculosis. Serological techniques to detect circulating antibodies are limited due to poor sensitivities. The PCR technique is faster than culture and offers the advantage of high sensitivity than other techniques.

Among all cattle and buffaloes screened by SICTT, buffaloes displayed more prevalence for bTB (10.2\%) as compared to cattle (1.3\%). The cattle tested positive belonged to an unorganised farm, while the buffaloes belonging to both organised (15 buffaloes) and unorganised farm (one buffalo) were tested positive. The probable reason for more number of buffaloes being positive could be more transmission of the disease among these animals as they were closely tied together at the farm thus enabling the spread of the disease while the cattle were in the separate shed within the farm. The numbers of positive reactors were more in the organised farm as compared to the unorganised farms. The present study was in accordance with the study conducted by Brahma et al. (2019), who reported that the prevalence was more in buffaloes as compared to cattle.

Higher positive response on skin testing was recorded in cattle and buffaloes in the age groups of 6-9 years $(52.94 \%$ of the positive reactors belonged to this age group). Different workers have reported a higher incidence of bovine tuberculosis with increased age (Munroe et al., 2000).

Four animals which were negative for TB with SICCT were positive with $\gamma$-IFN have also been reported by other workers (Gormley et al., 2004; Coad et al., 2008). The authors proposed that these animals might have been in the early stages of the disease, which could not be detected by SICCT. The IGRA assay detects the cytokine gamma-interferon, which is predominantly released by T-helper cells after in-vitro stimulation with bovine PPD and avian PPD. Release of $\gamma$ - IFN is measured by an EIA. Interferon $-\gamma$ is regarded as a pivotal cytokine released during the immune response to TB. It is produced by a wide variety of cell types but 
primarily by T-cells which, on exposure to mycobacterial antigen, release IFN- $\gamma$, which further starts a cascade of the immune response, most distinctly the activation of macrophages. Further, the presence of reactive T-cells indicates exposure to the organism; hence, IFN- $\gamma$ assay can help in the detection of mycobacterial infection at an early stage.

In the present study, $\gamma$-IFN assay exhibited more sensitivity than SICCT as four animals that were negative for TB with SICCT were positive with $\gamma$-IFN. However, the maximum overall sensitivity of $95.2 \%$ was claimed to have been achieved by testing with the IFN- $\gamma$ and the tuberculin test in correspondence (Wood et al., 1991; Liébana et al., 1999; Gormley et al., 2006). While bTB could be diagnosed by intradermal tuberculin test in 3-6 weeks postinfection, the gamma-IFN assay exposes the infection as shortly as 14 days post-infection (Ryan et al., 2000). Keck (2010) stated that the sensitivity of detection improved more than $30 \%$ by using $\gamma$-IFN assay in parallel with the skin test. Hence, synchronous examination of the animals in a herd by SICCT and INF- $\gamma$ leads to increase detection of TB in the dairy herds.

Cell-mediated immunity based test distinctly indicated that there is an infection in the herd; nevertheless, antibody detection by ELISA did not display positives in the present study. The reason could be that animals are in the initial stage of infection, where they are identified by only CMI based tests. Tuberculosis existing as a disease having a long incubation period will necessitate some course of time to have a humoral response. It can be regarded as a marker for advancing disease (Da La RuaDomenech et al., 2006; Da Silva et al., 2011). Cell-mediated immunity is predominant as compared to humoral immunity in mycobacterial infections. However, in the advanced stages of the disease and anergic animals, antibody detection is entirety the major

\section{REFERENCES}

Ahir P, Filia G, Mahajan V, Leishangthem GD, Rai TS et al., 2016. Diagnosis of bovine tuberculosis in lactating cattle and buffaloes diagnostic test (Cousins and Florission, 2005; DaSilva et al., 2011).

Molecular diagnosis by PCR using primers of a specific insertion sequence (IS6110) that is highly specific for MTBC was carried out, giving great specificity. Multiple copies of the IS6110 sequence are frequently considered to be present in genus Mycobacterium, presenting it as an attractive target sequence for PCR-based diagnosis (Chauhan et al., 2007).

In the present study, seventeen animals ( 1 cattle and 16 buffaloes) were positive for both PCR and SICCT. Six inconclusive SICTT reactors (2 cattle and 4 buffaloes) were tested positive by PCR. Nineteen ( 1 cattle and 18 buffaloes) were positive for both PCR and IFN$\gamma$. Four ( 2 cattle and 2 buffaloes) INF- $\gamma$ assay negative animals tested positive by PCR. The sensitivity of PCR for detection of MTC was more than all other tests. Results of the present study were similar to the study conducted by Bhanu Rekha et al. (2015) who concluded that after analysing all the diagnostic tests for tuberculosis detection, including acid-fast staining, fluorescent staining and culture methods, PCR identified the maximum number of positives $(n=4 / 181)$ and as compared to other tests it demonstrated higher sensitivity.

There is no individual test sufficient for detecting all animals infected with bTB; therefore, multiple diagnostic approaches involving tests based on cell-mediated immune response, humoral immune response and molecular techniques must be carried out concurrently for better diagnosis and control of the disease.

Conflict of interest: Authors have no conflict of interest in this study.

\section{ACKNOWLEDGEMENT}

The authors acknowledged the Director Research, GADVASU, for providing funds through Rashtriya Krishi VikasYojna for the study.

by comparative intradermal tuberculin test and bovine gamma-interferon immunoassay. J Anim Res, 6(6): 1069-1072, doi: 
10.5958/2277-940X.2016.00157.1

Bhanu RekhaV, Gunaseelan L, Pawar G, Nassiri $\mathrm{R}$ and Bharathy S, 2015. Molecular detection of Mycobacterium tuberculosis from bovine milk samples. J Adv Vet Anim Res, 2(1): 80-83, doi: 10.5455/javar. 2015.b44

Brahma D, Narang D, Chandra M, Filia G, Singh A et al., 2019. Diagnosis of bovine tuberculosis by comparative intradermal tuberculin test, interferon-gamma assay and esxB (CFP-10) PCR in blood and lymph node aspirates. Open J Vet Med, 9(5): 5565, doi: 10.4236/ojvm.2019.95005

Chauhan DS, Sharma VD, Parashar D, Chauhan A, Singh D et al., 2007. Molecular typing of Mycobacterium tuberculosis isolates from different parts of India based on IS6110 element polymorphism using RFLP analysis. Indian J Med Res, 125(4): 577581

Coad M, Downs SH, Durr PA, Clifton-Hadley RS, Hewinson RG et al., 2008. Blood-based assays to detect Mycobacterium bovis infected cattle missed by tuberculin skin testing. Vet Rec, 162(12): 382-384, doi: 10.1136/vr.162.12.382

Cousins DV and Florisson N, 2005. A review of tests available for use in the diagnosis of tuberculosis in non-bovine species. Rev Sci Tech, 24(3): 1039-1059

Da Silva EB, de Souza Silva BD, Leon JRR, Kipnis A, de Miranda Santos IKF et al., 2011.Using BCG, MPT-51 and Ag85 as antigens in an indirect ELISA for the diagnosis of bovine tuberculosis. Vet J, 187(2): 276-278, doi: 10.1016/j.tvj1. 2009.11 .017

De la Rua-Domenech R, Goodchild AT, Vordermeier HM, Hewinson RG, Christiansen KH et al., 2006. Antemortem diagnosis of tuberculosis in cattle: A review of the tuberculin tests, gamma-interferon assay and other ancillary diagnostic techniques. Res Vet Sci, 81(2): 190-210, doi: 10.1016/j.rvsc.2005.11.005
Figueiredo EES, Silvestre FG, Campos WN, Furlanetto LV, Medeiros L et al., 2009. Identification of Mycobacterium bovis isolates by a multiplex PCR. Braz J Microbiol, 40(2): 231-233, doi: 10.1590/ S1517-83822009000200004

Gormley E, Doyle MB, Fitzsimons T, Mcgill K and Collins JD, 2006. Diagnosis of M. Bovis infection in cattle by use of gammainterferon (Bovigam ${ }^{\circledR}$ ) assay. Vet Microbiol, 112(2-4): 171-179, doi: 10.1016/ j.vetmic.2005.11.029

Gormley E, Doyle MB, McGill K, Costello E, Good M et al., 2004. The effect of the tuberculin test and the consequences of a delay in blood culture on the sensitivity of a gamma-interferon assay for the detection of Mycobacterium bovis infection in cattle. Vet Immunol Immunopathol, 102(4): 413420, doi: 10.1016/j.vetimm.2004.08.002

Harrington NP, Surujballi OP, Prescott JF, Duncan JR, Waters WR et al., 2008. Antibody responses of cervids (Cervus elaphus) following experimental Mycobacterium bovis infection and the implications for immunodiagnosis. Clin Vaccine Immunol, 15(11): 1650-1658, doi: 10.1128/CVI.00251-08

Keck N, 2010. Tuberculose bovine en Camargue: apports du test à interféron gamma. Le Point Vet, 309: 54-57

Liébana E, Girvin RM, Welsh M, Neill SD and Pollock JM, 1999. Generation of CD8 (+) T- cell responses to Mycobacterium bovis and mycobacterial antigen in experimental bovine tuberculosis. Infect Immun, 67(3): 1034-1044, doi: 10.1128/IAI.67.3.10341044.1999

Mackay CR and Hein WR, 1989. A large proportion of bovine T cells express the $\gamma \delta$ $\mathrm{T}$ cell receptor and show a distinct tissue distribution and surface phenotype. Int Immunol, 1(5): 540-545, doi: 10.1093/ intimm/1.5.540

Munroe FA, Dohoo IR and McNab WB, 2000. Estimates of within-herd incidence rates of 
Mycobacterium bovis in Canadian cattle and cervids between 1985 and 1994. Prev Vet Med, 45(3-4): 247-256, doi: 10.1016/ s0167-5877(00)00126-4

Neill SD, Bryson DB and Pollock JM, 2001. Pathogenesis of tuberculosis in cattle. Tuberculosis (Edinb), 81(1-2): 79-86, doi: 10.1054/tube.2000.0279

Ryan TJ, Buddle BM and De Lisle GW, 2000. An evaluation of the gamma interferon test for detecting bovine tuberculosis in cattle 8 to 28 days after tuberculin skin testing. Res Vet Sci, 69(1): 57-61, doi: 10.1053/ rvsc. 2000.0386

Wadhwa A, Hickling GJ and Eda S, 2012. Opportunities for improved serodiagnosis of human tuberculosis, bovine tuberculosis, and paratuberculosis. Vet Med Int: 674238, doi: 10.1155/2012/674238

Waters WR, Buddle BM, Vordermeier HM,
Gormley E, Palmer MV et al., 2011. Development and evaluation of an enzymelinked immunosorbent assay for use in the detection of bovine tuberculosis in cattle. Clin Vaccine Immunol, 18(11): 1882-1888, doi: 10.1128/CVI.05343-11

Welsh MD, Cunningham RT, Corbett DM, Girvin RM, McNair J et al., 2005. Influence of pathological progression on balance between cellular and humoral immune responses in bovine tuberculosis. Immunology, 114(1): 101-111, doi: 10.1111/ j.1365-2567.2004.02003.x

Wood PR, Corner LA, Rothel JS, Baldock C, Jones SL et al., 1991. Field comparison of the interferon-gamma assay and the intradermal tuberculin test for the diagnosis of bovine tuberculosis. Aust Vet J, 68(9): 286-290, doi: 10.1111/j.1751-0813.1991. tb03254.x 